\title{
The Troodos ophiolite: petrology of a fresh glassy basalt
}

\author{
KARL A. JØRGENSEN and C. K. BROOKS
}

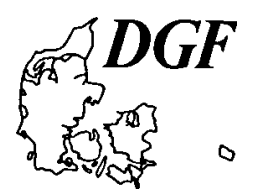

Jørgensen, K. A. \& Brooks, C. K.: The Troodos ophiolite: petrology of a fresh glassy basalt. Bull. geol. Soc. Denmark, vol. 30, pp. 43-50. Copenhagen, November 12th, 1981. https://doi.org/10.37570/bgsd-1981-30-03

\begin{abstract}
Droplets of rapidly quenched, silicic tholeiite glass are described, which are relatively unaltered except for the absorption of about $6 \% \mathrm{H}_{2} \mathrm{O}$. The glass is variolitic and contains minor olivine, chromite, clinopyroxene and plagioclase of various habits, whose relationships to cooling history may be deduced in the light of experimental data and whose compositions are reported. It is suggested from this reconnaissance study that the Troodos Upper Pillow Lavas have most probably formed at a spreading centre, perhaps a back-arc environment, rather than an island arc.
\end{abstract}

K. A. Jørgensen and C. K. Brooks, Institute of Petrology, Øster Voldgade 10, 1350 København, Denmark, February 25th, 1981.

\section{Introduction}

The Troodos ophiolite complex, Cyprus, is generally considered to be the best investigated ophiolite complex in the world (Coleman, 1977). Nevertheless, its origin has been the subject of much debate with several authors (Gass, 1968; Gass et al., 1975; Hynes, 1975) defending a midocean ridge (MOR) origin against the volcanic arc hypothesis proposed by Miyashiro (1973, 1975). More recently, Smewing et al. (1975) and Smewing and Potts (1976) have convincingly advocated a MOR origin on the basis of rare earth element data. Geochemical conclusions have been greatly hampered by the altered nature of most of the Troodos extrusive rocks.

The main purpose of the present work is to demonstrate that fresh glasses are to be found among the Troodos lavas and to describe one example which provides an excellent natural example of textures produced experimentally under various cooling conditions. The glassy sample is not unique, (Cameron et al. 1979), and the authors' collection has recently been considerably augmented by further glasses which it is hoped can contribute towards a solution of the above controversy.

\section{Geological setting}

The investigated sample comes from the upper part of the Upper Pillow Lava member of the ophiolite complex (Gass and Smewing 1973) in the area of Kalavassos. It was collected near the top of the section described by Searle and Vokes (1969) from the north side of the Vasilikos river valley opposite the Hellenic Mining Company's offices. At this locality, just above the prominent picrite sheet flow overlying deep-sea sediments (Searle \& Vokes, 1969, fig. 2) there is a thin horizon, in which glassy micropillows or balls occur in a fine grained hyaloclastite matrix. These balls apparently represent rapidly quenched lava droplets. Several of the horizons of this profile are relatively fresh and are worthy of further study

\section{Sample description}

The investigated sample is a micropillow of about $3 \mathrm{~cm}$ diameter, which typically consists largely of isotropic glass (59.4 vol\%) with olivine phenocrysts $(3.9 \%)$, spinel microphenocrysts $(0.25 \%)$, abundant feathery aphenilites or varioles $(32.4 \%)$ and minor alteration products $(4.1 \%)$. The modal values given in brackets are based on 2036 point counts.

The glass is isotropic, transparent and structureless, but has a distinct greenish tinge, unlike the colourless or brownish colour found in recent basaltic glasses. It is transected by curved, branching palagonite veins; which are up to 0.1 $\mathrm{mm}$ thick and occur with a density of about 2 per $\mathrm{cm}$. Numerous fine, almost submicroscopic 
Table 1.

Analysis of glass from Kalavassos.

\begin{tabular}{|c|c|c|c|c|}
\hline & Average & $0^{x)}$ & CIP & $\operatorname{corm}^{x x)}$ \\
\hline $\mathrm{SiO}_{2}$ & 52.57 & .57 & $Q z$ & 9.28 \\
\hline $\mathrm{Al}_{2} \mathrm{O}_{3}$ & 14.86 & .16 & Or & .74 \\
\hline $\mathrm{TiO}_{2}$ & .41 & .04 & $A b$ & 12.79 \\
\hline $\mathrm{FeO}^{\dagger}$ & 6.99 & .36 & $A_{n}$ & 35.59 \\
\hline $\mathrm{MnO}$ & .12 & .03 & $\mathrm{Di}$ & 19.43 \\
\hline $\mathrm{MgO}$ & 7.25 & .09 & $\mathrm{Hy}$ & 20.10 \\
\hline $\mathrm{CaO}$ & 11.42 & .16 & Mt & 1.41 \\
\hline $\mathrm{Na}_{2} \mathrm{O}$ & 1.44 & .06 & II & .82 \\
\hline $\mathrm{K}_{2} \mathrm{O}$ & .12 & .02 & Ap & .05 \\
\hline $\mathrm{P}_{2} \mathrm{O}_{5}$ & .024 & .019 & & \\
\hline Sum & 94.90 & & & \\
\hline
\end{tabular}

x) based on 9 microprobe analyses.

xx) calculated with $\mathrm{Fe}_{2} \mathrm{O}_{3} / \mathrm{FeO}=0.15$, (Brooks, 1976). cracks radiate from these veins out into the surrounding glass. Larger areas of palagonite and calcite often occur around the larger olivine phenocrysts and within the largest glass inclusions in these.

The glass (table 1) is a silicic, low alkalic tholeiite with a Thornton-Tuttle index of 22.8 and an $\mathrm{FeO}^{\text {tot }} / \mathrm{MgO}$ ratio of 0.96 . Its silicic nature combined with the high $\mathrm{MgO}$ and a rather low $\mathrm{TiO}_{2}$ content are features reminiscent of boninites (Shiraki et al., 1978) as suggested by Cameron et al. (1979). Some modification may have taken place during variole formation and the low sum and colour of the glass indicates that hydration has also occurred (to the extent of

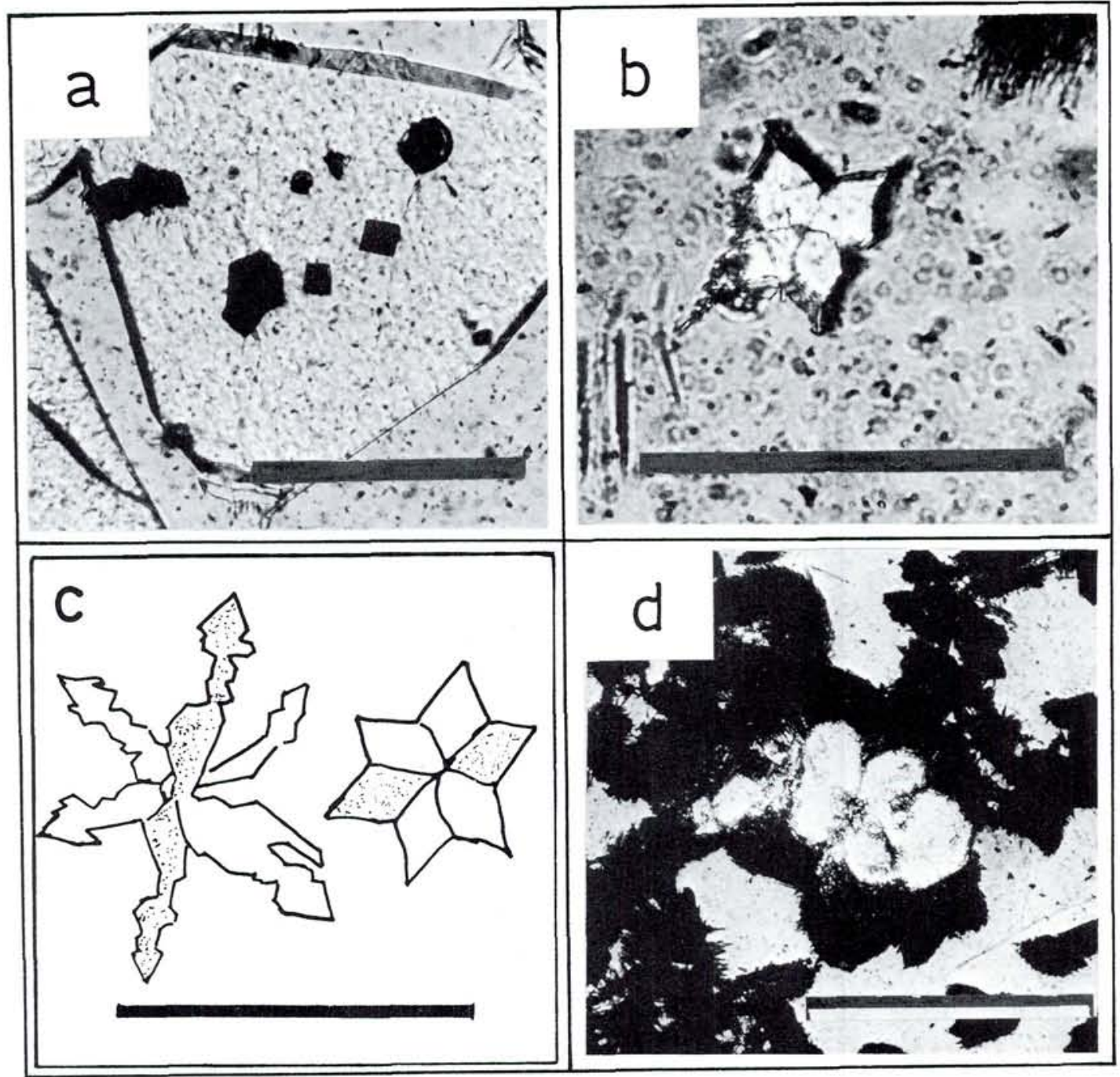

Fig, 1. a) Equant olivine with spinel inclusions. b) Radial olivine. c) Radial olivines, one with spikes, transitional to swallow tail type drawn from photographs. d) Group of equant clinopyroxencs and varioles with nucleii. Bar $100 \mu \mathrm{m}$. 
about $6 \% \mathrm{H}_{2} \mathrm{O}$ (microprobe analysis by difference)) and this may have influenced the alkalisilica relationships. However, the fact that $\mathrm{MgO}+\mathrm{FeO}$ are apparently in equilibrium with olivine (see below) suggests that any modifications after quenching have been minor.

The glass is devoid of vesicles and glass inclusions in the olivines do not contain vapour bubbles larger than can be explained as a result of differential thermal contraction between liquid (glass) and olivine as described by Andersson (1974). Quenching has thus taken place at sufficient depth to retain in solution any magmatic gases, as would be expected from the general setting.

The olivines show a wide range of morphologies, all of which can be closely matched with those observed by Donaldson, (1976) in olivines produced experimentally by different degrees or undercooling, and his nomenclature is therefore adopted here. The most conspicious types are large (up to $2.5 \mathrm{~mm}$ ) euhedral individuals with well formed faces and generally somewhat elongated in the $c$ direction, (Fig. 1a). These euhedral olivines, which broadly correspond to

Selected mineral analyses from the Kalavassos glass.

\begin{tabular}{|c|c|c|c|c|}
\hline & olivine & spinel & $\begin{array}{l}\text { cpx } \\
\text { euhedral }\end{array}$ & $\begin{array}{l}\text { cpx } \\
\text { feathery }\end{array}$ \\
\hline $\mathrm{SiO}_{2}$ & 39.60 & .10 & 50.87 & 50.22 \\
\hline $\mathrm{Al}_{2} \mathrm{O}_{3}$ & .05 & 17.74 & 3.52 & 6.25 \\
\hline $\mathrm{TiO}_{2}$ & .07 & .31 & .22 & .51 \\
\hline $\mathrm{FeO}^{f}$ & 12.02 & 20.81 & 6.17 & 7.06 \\
\hline $\mathrm{MnO}$ & .15 & .36 & .19 & .13 \\
\hline $\mathrm{MgO}$ & 46.36 & 12.52 & 18.59 & 16.15 \\
\hline $\mathrm{CaO}$ & .22 & .02 & 17.63 & 19.01 \\
\hline $\mathrm{Na}_{2} \mathrm{O}$ & .00 & .00 & .09 & .18 \\
\hline $\mathrm{Cr}_{2} \mathrm{O}_{3}$ & .13 & 45.00 & .24 & .20 \\
\hline Sum & 98.60 & 96.86 & 97.52 & 99.71 \\
\hline
\end{tabular}

No. of oxygens in formula

\begin{tabular}{llccc} 
& \multicolumn{1}{l}{4} & \multicolumn{1}{l}{32} & \multicolumn{1}{l}{6} & \multicolumn{1}{l}{6} \\
$\mathrm{Si}$ & .996 & .03 & 1.893 & 1.844 \\
$\mathrm{Al}$ & 002 & 5.38 & .154 & .270 \\
$\mathrm{Ii}$ & .002 & .06 & .006 & .014 \\
$\mathrm{Fe}^{3+}$ & - & 1.29 & .046 & .021 \\
$\mathrm{Fe}^{2+}$ & .253 & 3.20 & .146 & .196 \\
$\mathrm{Mn}$ & .003 & .08 & .006 & .004 \\
$\mathrm{Mg}$ & 1.738 & 4.81 & 1.031 & .884 \\
$\mathrm{Ca}$ & .006 & .01 & .703 & .748 \\
$\mathrm{Na}$ & - & - & .006 & .013 \\
$\mathrm{Cr}$ & .003 & 9.16 & .007 & .006
\end{tabular}

Donaldson's polyhedral type, may be overgrown by skeletal spikes, which protude from the corners and edges.

Another olivine type consists of a variety of hollow, skeletal olivines, which range in size up to $0.3 \mathrm{~mm}$ and show combinations of corneredge growths giving rise to double arrows, anchors, lanterns and similar shapes. These correspond to Donaldson's hopper morphology.

Smaller equant crystals (size order $0.05 \mathrm{~mm}$ ) have four gently curving fibres extending from the edges and similar fibres may occur on the edges of the hopper crystals. These are swallowtail types of Donaldson. Of similar size order are radial aggregates of 4-6 pointed twinned individuals (Fig. 1b,c). In the varioles, chains of $\mathrm{H}$ shaped olivine individuals, with a size of up to $0.01 \mathrm{~mm}-0.1 \mathrm{~mm}$ are common as nuclei for the arching, feathery pyroxene fibres, which constitute the major part of the variole.

The olivine is forsteritic (table 2) ranging in composition from $\mathrm{Fo}_{88.2}$ to $\mathrm{Fo}_{86.6}$ based on 19 analyses of all morphological types) with a maximum normal zonation of $1.2 \%$ Fo. The microphenocrysts are slightly less magnesian than the phenocrysts.

Clusters of tiny, transparent, red-brown to opaque microphenocryst of chrome spinel are commonly found as inclusions in the polyhedral olivines (Fig. 1a), but may also occur as discrete crystals forming nuclei for the varioles. These crystals have a size of around $0.02 \mathrm{~mm}$. There seems to be a transition from translucent crystals in the centres of the large polyhedral olivines to opaque ones in the rims and matrix glass, but this is not reflected in their compositions as the intercrystal variation is extremely small, implying an absence of subsolidus reactions. They are titanium-poor chromites with a minor ferric component as judged by their stoichiometry (Table 2).

Clinopyroxenes occur in two distinct habits: a) rare, equant, colourless, perfectly euhedral individuals up to $0.1 \mathrm{~mm}$ in size, which often show sieve texture due to numerous glass inclusions, Fig. 1d and b) abundant feathery, branching aggregates which constitute more than half of the varioles. This second type is often intergrown with plagioclase of the flabelliform type illustrated by Bryan (1972, Fig. 2a) and is characterized by strongly undulatory extinction, 


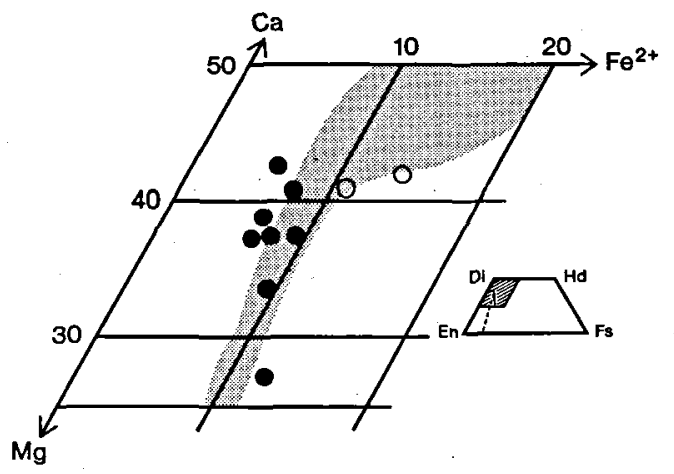

Fig. 2. Compositions of pyroxenes in terms of $\mathrm{Ca}-\mathrm{Mg}-\mathrm{Fe}^{2+}$. Filled circles: euhedral crystals, open circles: feathery crystals from varioles, fields $\mathrm{A} \& \mathrm{~B}$ are the quench and normal trends of Smith and Lindsley (1971). The inset shows the location of the larger diagram and orientation of the clinopyroxeneolivine tie-line which is clearly different from the observed data spread. Stippled field: Troodos pyroxenes from Cameron et al. (1979).

whereas the euhedral type may show hourglass zoning. The euhedral microphenocrysts are endiopsides (Table 2) of variable composition characteristic of rapidly crystallized groundmass pyroxenes (Smith and Lindsley, 1971) with an average of around $\mathrm{Ca}_{38} \mathrm{Mg}_{54} \mathrm{Fe}_{8}$. The feathery pyroxene of the varioles (Table 2 ) is more alumina- and iron-rich ( $\max . \mathrm{Ca}_{41}, \mathrm{Mg}_{44}, \mathrm{Fe}_{14}$ ) than the microphenocrysts and clearly plots off the trend defined by these (Fig. 2).

As already mentioned, plagioclase occurs in intergrowths as a minor constituent of the varioles along with clinopyroxene. Some varioles are of monomineralic plagioclase with cores of the swallow-tail type as illustrated by Mäkipää (1978, Fig. 10b). All plagioclases are too finegrained to permit analysis.

\section{Cooling conditions}

From the interrelationships of the different phases and their different morphologies, the crystallization sequence shown in Fig. 3 can be deduced. In addition, by comparison with experimental systems (Donaldson, 1976; Hill and Roeder, 1974; and Lofgren, 1974) the approximate cooling rates for the different morphologies can be deduced as summarized in Fig. 4.

The olivine morphologies are dependent on

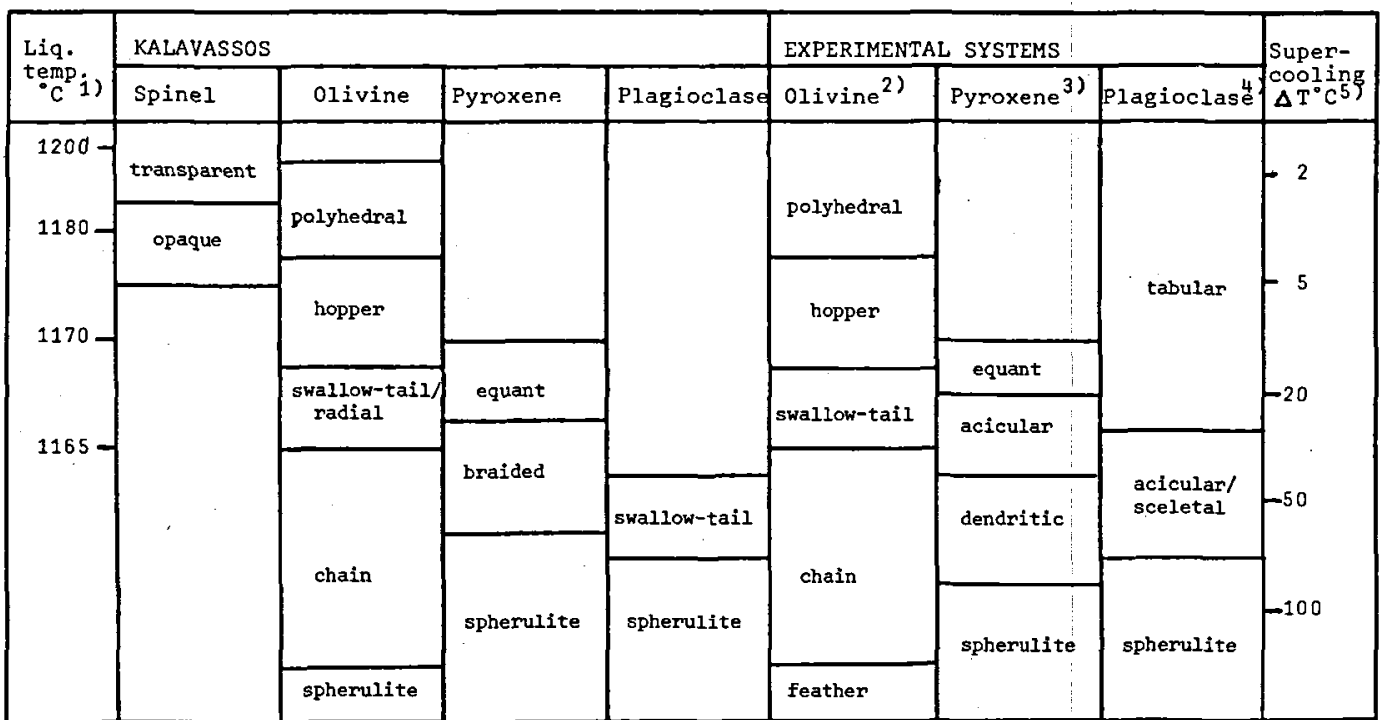

Explanation: 1) estimated liquidus temperatures for the natural system, adopted from Hill and Roeder (1974). 2) averaged morphology change from Donaldsson (1976). 3)and4)pyroxene and plagioclase morphology change as a function of supercooling after Lofgren (1974). 5)degree of supercooling averaged trom the experimental systems.

Fig. 3. Crystallization sequence compared with experimental systems. Liquidus temperatures estimated from the natural system based on Hill and Roeder (1974) olivine morphologies from Donaldson (1976), experimental pyroxene and plagioclase morphologies after Lofgren (1974) and degrees of supercooling averaged from these experimental systems. 


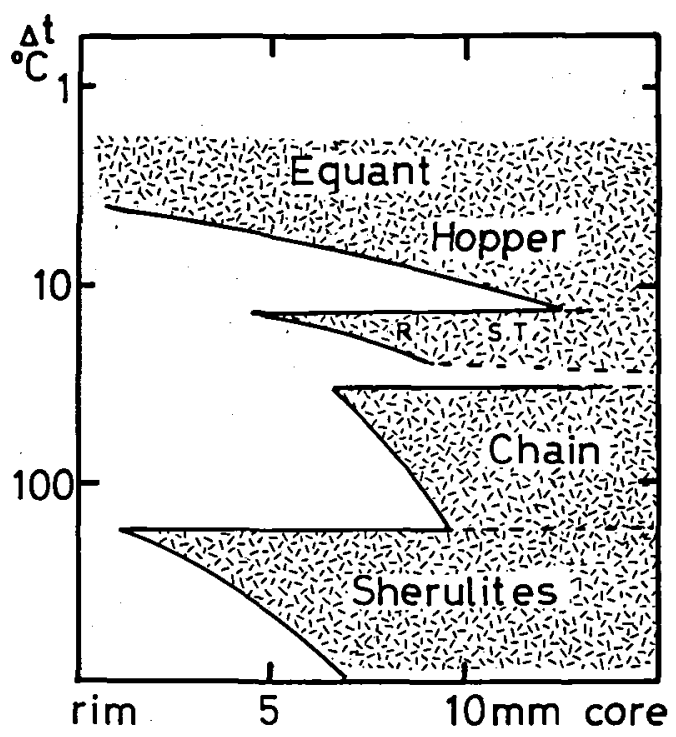

Fig. 4. Distribution of olivine morphologies in the pillow versus degree of supercooling averaged from the experimental systems (Donaldson, 1976; Hill and Roeder, 1974). Width of dashed wedge indicates relative abundance of relevant morphologies. R: radial olivines. ST: swallow tail morphology.

the distance from the pillow rim (Fig. 5), in accordance with observations from larger pillows (Kirkpatrick, 1978; Swanson and Schiffman, 1979), indicating that the cooling rate decreased away from the rim allowing for the appearance of more morphologies. The twinned radial olivines are important in this connection, as they are very rare in nature, the only other descrip-

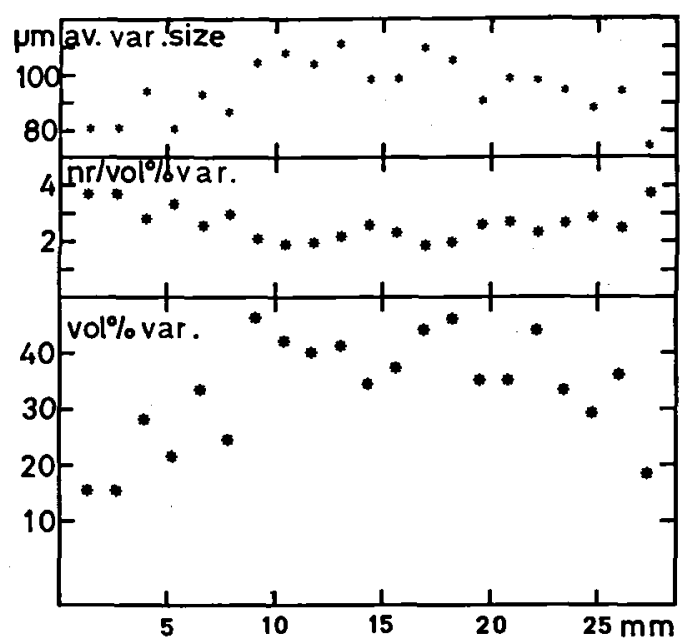

Fig. 5. Cross section through the pillow, showing distribution of varioles expressed as vol \% (based on 121 points $/ 1.7 \mathrm{~mm}^{2}$ ), number of varioles/vol \% and average variole size. tion being from the Taiwan coast ophiolite (Liou, 1974). They apparently form under very restricted conditions, as also evidenced from this study, where they only occur between 4 and 7 $\mathrm{mm}$ from the rim. According to Donaldson (1976) they only form at supercooling around $20^{\circ} \mathrm{C}$, indicating this magnitude of supercooling 4 $\mathrm{mm}$ from the rim immediately after the magma flow had stopped, thus explaining the concentric occurrence. The random occurrence of hopper morphologies, on the other hand, indicates flow at this supercooling $\left(5\right.$ to $10^{\circ} \mathrm{C}$.).

The pyroxene microcrysts occur somewhat more orderly, indicating that the magma flow stopped, when the supercooling was between 15 and $20^{\circ} \mathrm{C}$. The asymetric distribution of varioles (Fig. 5) is due to the heating effect from underlying pillows.

The compositions of coexisting olivine and glass can be used as a geothermometer (Roeder and Emslie, 1970; Roeder, 1974 and Bender et al., 1978), provided that they are in equilibrium. One possible test of the equilibrium is provided by the $\mathrm{Mg}-\mathrm{Fe}$ distribution coefficient, $\mathrm{K}_{\mathrm{D}}$ :

$$
\mathrm{K}_{\mathrm{D}}=\left(\frac{\mathrm{FeO}}{\mathrm{MgO}}\right)^{\text {ol }} /\left(\frac{\mathrm{MgO}}{\mathrm{FeO}}\right)^{\text {liq }}
$$

which should have a value of close to 0.30 (Roeder, 1974). For the Kala vassos sample $K_{D}$ $=0.305$ for an assumed $\mathrm{Fe}_{2} \mathrm{O}_{3} / \mathrm{FeO}$ ratio of 0.15 which is taken to indicate that the olivine-glass

Table 3.

Olivine-glass equilibrium temperatures for the Kalavassos sample in ${ }^{\circ} \mathrm{C}$.

\begin{tabular}{|l|c|c|}
\hline & $A$ & $B$ \\
\hline R\&E & 1171 & -- \\
${ }^{R_{M g O}}$ & 1182 & 1256 \\
${ }^{R_{F e O}}$ & 1190 & 1236 \\
$R_{\mathrm{MnO}}$ & 1171 & -- \\
${ }{ }_{M g O} / \mathrm{FeO}$ & -- & 1198 \\
\hline
\end{tabular}

Based on equations of A: Roeder and Emslie (1970) (R\&E) and Roeder (1974) and B: Bender ef al. (1978) with assumed $\mathrm{Fe}_{2} \mathrm{O}_{3} / \mathrm{FeO}=0.15$ in $\mathrm{A}$, total $\mathrm{FeO}$ in $\mathrm{B}$ and olivine $\mathrm{Fo}_{87,3}$. 
pair is in equilibrium. Care must however be taken as Takahashi (1979) showed that $K_{D}$ was dependent on liquid composition. Olivine crystallization temperatures range from $1171^{\circ} \mathrm{C}$ to $1256^{\circ} \mathrm{C}$ though the temperatures around $1180^{\circ} \mathrm{C}$ (Table 3) are considered most likely.

\section{Palaeotectonic environment}

Though it is difficult to determine the palaeotectonic environment from a single sample compositional evaluations of the single components constituing the sample may together give an environmental indication.

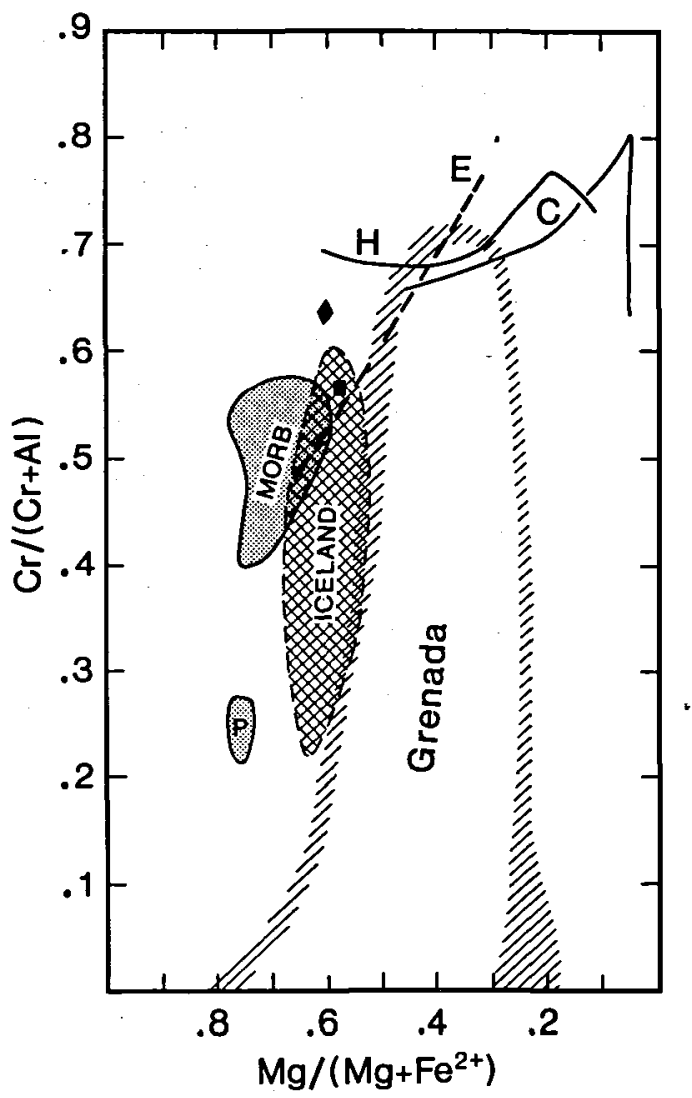

Fig. 6. Compositions of spinels from various environments. Diamond; Kalavassos spinels (5 analyses); spotted fields; MidAtlantic Ridge (Sigurdsson and Schilling, 1976), cross hatched; Iceland alkalic basalts (Thy, pers. com., 1980), Grenada field (Arculus, 1978), filled square; Niuafa'ou, Tonga (Reay et al., 1974), trend line 'H'; Hawaii (Evans and Moore, 1968; Evans and Wright, 1972); trend line ' $C$ '; East Island, Crozet (Gunn et al., 1970) and trend line ' $E$ '; pre-Etnean tholeiites, Etna (Tanguy, 1978). Compare with similar diagram in Cameron et al. (1979), fig. 3.
The glass composition itself, though high in silica, is reminiscent of many abyssal glasses, with its low $\mathrm{K}_{2} \mathrm{O}$, $\mathrm{TiO}_{2}$ and $\mathrm{Al}_{2} \mathrm{O}_{3}$, (Schweitzer et al., 1978).

The olivines and clinopyroxenes from the Kalavassos glass are not diagnostic, but are generally more common in MOR environments (Schweitzer et al., 1978) than in island arc environments, (Ewart, 1976).

The Cr-spinels (Fig. 6) are slightly more chromian than generally found in MOR basalts (Sigurdsson and Schilling, 1976), but falls within the field known from oceanic islands (Evans and Moore, 1969; Evans and Wright, 1972; Gunn et al., 1970; Thy, pers. comm., 1980), while typical island arc spinels have a considerably larger spread (Arculus, 1978; Tanguy, 1978) and boninite spinels in general are much higher in $\mathbf{C r}$ (Cameron et al., 1979).

The overall tendency, however, seems to be a strong resemblance to rocks from back-arc spreading centres (Saunders and Tarney, 1978; Gill, 1976) or similar environments (Reay et al., 1974; Johnson and Arculus, 1978) although the Troodos sample is remarkably low in $\mathrm{TiO}_{2}$ for both glass and minerals, and in general invites comparison with boninites (Shiraki et al., 1978) as noted above and also suggested by Cameron et al., (1979). However, Nesbit and Sun (1980) shows that the boninites have a distinctly different $\mathrm{Ti} / \mathrm{Zr}$ ratio indicating anomalous genetic conditions, while the ratio for Troodos lavas are "normal" with regard to MOR and flood basalt volcanism. Wood, (1979) further showed that dynamic partial melting of a plagioclase lherzolite source could reproduce all observed REE patterns in the Troodos without involving the presence of hydrous phases generally accepted as necessary for the production of boninites.

\section{Conclusions}

The present reconnaissance study of a single sample of unaltered basaltic glass from the Troodos ophiolite complex has defined the magma composition, the cooling conditions and the quenching temperature. It lends some support to the idea that these rocks were formed in a back-arc spreading environment but not to the island arc hypothesis. 
Acknowledgements. We thank the late Michael Mantis and Costas Xenophontos of the Geological Survey of Cyprus for excellent guidance during a student excursion to the island.

\section{Dansk sammendrag}

Dråber af tholeitisk glas beskrives. De er forholdsvis uomdannede på nær ca. $6 \%$ absorption af vand.

Glasset er variolitisk med små mængder af olivin, chromit, clinopyroxen og plagioklas. Mineralerne viser varierende habitus, som kan tolkes i forhold til afkølingshistorien på baggrund af experimentelle data. På grundlag af dette forløbige studie foreslås de, at de фvre pudelavaer fra Troodos sandsyn. ligvis blev dannet ved et spredningscentrum, måske bag en øbue og ikke ved selve øbuen.

\section{References}

Anderson, A. T. 1974: Evidence for a picritic, volatile-rich magma beneath Mt. Shasta, California. J. Petrology 15: 243-267.

Arculus, R. J. 1978: Mineralogy and petrology of Grenada, Lesser Antilles Island Arc. Contrib. Mineral. Petrol., 65: 413-424.

Bender, J. F., Hedges, F. N. and Bence, A. E. 1978: Petrogenesis of basalts from the project FAMOUS area: experimental study from 0 to 15 kbars. Earth Planet. Sci. Lett. 41: 277-302.

Brooks, C. K. 1976: The $\mathrm{Fe}_{2} \mathrm{O}_{3} / \mathrm{FeO}$ ratio of basalt analyses: an appeal for a strandardized procedure. Bull. Geol. Soc. Denmark, 25: 117-119.

Bryan, W, B. 1972: Morphology of quench crystals in submarine basalts. J. Geophys. Res., 77: 5812-5819.

Cameron, W. E., Nisbet, E. G. and Dietrich, V. J. 1979: Boninites, komatiites and ophiolitic basalts. Nature, 280: 550-553.

Coleman, R. G. 1977: Ophiolites. Springer Verlag. BerlinNew York 229 pp.

Donaldson, C. H. 1976: An experimental investigation of olivine morphology. Contrib. Mineral. Petrol., 57: 187214.

Evans, B. W. and Moore, J. G. 1968: Mineralogy as a function of depth in the prehistoric Makaopuhi lava lake, Hawaii. Contrib. Mineral. Petrol., 17: 85-115.

Evans, B. W. and Wright, T. L. 1972: Composition of liquidus chromite from the 1959 (Kilauea Iki) and 1965 (Makaopuhi) eruptions of Kilauea volcano, Hawaii. Am. Mineral., 57: 217-230.

Ewart, A. 1976: Mineralogy and chemistry of modern orogenic lavas- some statistics and implications. Earth Planet. Sci. Lett., 31: 417-432.

Gass, I. G. 1968: Is the Troodos massif of Cyprus a fragment of Mesozoic ocean floor. Nature, 220: 39-42.

Gass, I. G. and Smewing, J. D. 1973: Intrusion, extrusion and metamophism at constructive margins: Evidence from the Troodos massif, Cyprus. Nature, 242: 26-29.

Gass, I. G., Neary, C. R., Plant, J., Robertson, A. H. F., Simonian, K. O., Smewing, J. D., Spooner, E. T. C. and Wilson, R. A. M. 1975: Comments on 'The Troodos ophiolite complex was probably formed in an island arc' by $\mathrm{A}$. Miyashiro and subsequent correspondence by $\mathrm{A}$. Hynes and A. Miyashiro. Earth Planet. Sci. Lett., 25: 236-238.
Gill, J. B. 1976: Composition and age of Lau Basin and Ridge volcanic rocks: Implications for evolution of an interarc basin and remnant arc. Bull. Geol. Soc. Am., 87: 13841395.

Gunn, B. M., Coy-Yll, R., Wathins, N. D., Abranson, C. E. and Nougier, J. 1970: Geochemistry of an oceanite-ankaramite-basalt suite from East Island, Crozets Islands. Contrib. Mineral. Petrol., 28: 319-339.

Hill, R. and Roeder, P. 1974: The crystallization of spinel from basaltic liquid as a function of oxygen fugacity. $J$. Geol., 82: 709-730.

Hynes, A. 1975: Comment on 'The Troodos ophiolitic complex was probably formed in an island arc' by A. Miyashiro. Earth Planet. Sci. Lett., 25: 213-216.

Johnson, R. W. and Arculus, R. J. 1978: Volcanic rocks of the Witu Islands, Papua New Guinea: The origin of magmas above the deepest part of the New Britain Benioff zone. Bull. Volc., 41: 609-655.

Kirkpatrick, R. J. 1978: Processes of crystallization in pillow basalts, Hole 396B, DSDP LEG46. In: Dmitriev, L., Heirtzler, J. et al.: Initial reports of the Deep Sea Drilling Project, 46: 271-282.

Liou, J. G. 1974: Mineralogy and chemistry of glassy basalts, Coastal Range ophiolites, Taiwan. Bull. Geol. Soc. Am., 85: 1-10.

Lofgren, G. 1974: An experimental study of plagioclase crystal morphology: Isothermal crystallization. Am. J. Sci., 274: 243-273.

Melson, W. G., Thompson, G. and van Andel, T. H. 1968: Volcanism and metamorphism in the Mid Atlantic Ridge, $22^{\circ}$ N. latitude. J. Geophys. Res., 73: 5925-xxxx.

Miyashiro, A. 1973: The Troodos ophiolitic complex was probably formed in island arc. Earth Planet. Sci. Lett., 19: 218-224.

Miyashiro, A. 1975: Origin of the Troodos and other ophiolites: replies to Hynes and Moores. Earth Planet. Sci. Lett., 25: 217-222, 227-235.

Mäkipää, H. 1978: Petrological relations in some icelandic basaltic hyaloclastites. Bull. Geol. Soc. Finland, 50: 81112.

Nesbitt, R. W. and Sun, S.-S. 1980: Geochemical features of some archaean and post-archaean high-magnesian- lowalkali liquids. Phil. Trans. R. Soc. Lond., A,297, 365381.

Reay, A., Rooke, J. M., Wallace, R. C. and Wheelan, P. 1974: Lavas from Niuafo'ou Island, Tonga, resemble ocean floor basalts. Geology, 2: 605-606.

Roeder, P. L. 1974: Activity of iron and olivine solubility in basaltic liquids. Earth Planet. Sci. Lett., 23: 397-410.

Roeder, P. L. and Emslie, R. F. 1970: Olivine-liquid equilibria. Contrib. Mineral. Petrol., 29: 275-289.

Saunders, A. D. and Tarney, J. 1979: The geochemistry of basalts from a back-arc spreading centre in the East Scotia Sea. Geochim. Cosmochim. Acta., 43: 555-572.

Schweitzer, E. L., Papike, J. J. and Bence, A. E. 1978: Clinopyroxenes from deep-sea basalts: A statistical analysis. Geophys. Research Lett., 5: 573-576.

Searle, D. L. and Vokes, F. M. 1969: Layered ultrabasic lavas from Cyprus. Geol. Mag., 106: 515-530.

Shiraki, K., Kuroda, N., Maruyama, S. and Urano, H. 1978: Evolution of the Tertiary volcanic rocks in the IzuMariana arc. Bull. Volc., 41: 548-562.

Sigurdsson, H. and Schilling, J.-G. 1976: Spinels in MidAtlantic Ridge basalts; Chemistry and occurence. Earth Planet. Sci. Lett., 29: 7-20.

Smewing, J. D. and Potts, P. J. 1976: Rare Earth abundances in basalts from the Troodos massif, Cyprus. Contrib. Mineral. Petrol., 57: 245-258. 
Smewing, J. D., Simonian, K. O. and Gass, I. G. 1975: Metabasalts from the Troodos massif, 'Cyprus: Genetic implication deduced from petrography and trace element geochemistry. Contrib. Mineral. Petrol., 51: 49-64.

Smith, D. and Linsley, D. H. 1971: Stable and metastable augite crystallization trends in a single basalt flow. $\mathrm{Am}$. Mineral., 56: 225-233.

Swanson, S. E. and Schiffman, P. 1979: Textural evolution and metamorphism of pillow basalts from the Franciscan Complex, Western Marin County, California. Contrib. Mineral. Petrol., 69: 291-299.
Takahashi, E. 1979: Partitioning of $\mathrm{Ni}^{2+}, \mathrm{Co}^{2+}, \mathrm{Fe}^{2+}, \mathrm{Mn}^{2+}$ and $\mathrm{Mg}^{2+}$ between olivine and silicate melts: Compositional depence of partitioning coefficients. Geochim. Cos. mochim. Acta, 42: 1829-1844.

Tanguy, J. C. 1978: Tholeiitic basalt magmatism of Mount Etna and its relations with the alkaline series. Contrib. Mineral. Petrol., 66: 51-68.

Wood, D. A. 1979: Dynamic partial melting: its application to the petrogeneses of basalts erupted in Iceland, the Faeroe Islands the Isle of Skye (Scotland) and the Troodos Massif (Cyprus). Geochim. Cosmochim. Acta, 43: 1013-1046. 